interpretation from the proliminary publications have resulted from the more detailed study.

Physics Department,

G. DE Q. ROBIN

University of Birmingham, Edgbaston,

Birmingham 15.

Dec. 23.

1 Poulter, T. C., "Geophysical Studies in the Antarctic" (Stanford Research Institute, California, 1950); Trans. Amer. Geophys. Union, 28, No. 2, 162 (1947): 28, No.

${ }^{2}$ Robin, G. de Q., Nature, 171, 55 (1953).

${ }^{3}$ Robin, G. de Q., J. Glaciol., 2, 205 (1953). Holtzscherer, J. J., and Robin, G. de Q., Gleog. J., 120, 197 (1954).

s Schytt, V., Geog. Rev., 44, 70 (1954).

\section{Control of the Staining Procedure after Paper Electrophoresis}

WHEN quantitative techniques are attempted for the analysis of serum proteins separated by electrophoresis on filter paper, it is recognized that the staining procedure, followed by removing the surplus stain, constitutes sources of error. In order to get more satisfactory reproducibility we apply on each paper strip (after electrophoresis but before staining) $0.02 \mathrm{ml}$. of a 0.05 per cent solution of polyethylenimine (Badische Anilin und Sodafabrik, Kudwigshafen (Germany) ) in water. This polybase, $-\left[-\mathrm{CH}_{2}\right.$ $\left.-\mathrm{CH}_{2}-\mathrm{NH}_{2}-\right]_{n}-$, has the advantage of being stained by naphthalene black $12 B$ as well as by sudan black; therefore it can be used equally well as a reference substance for protein staining and lipoprotein staining. The molecule (mol. weight approx. 30,000-40,000) of the polybase (called 'Polymine') is of linear build and possesses such an affinity for cellulose that the stained spots cannot easily be eluted but must be estimated by direct-reading colorimetry. The paper strip $a$ (see Fig. 1) shows the separation of normal serum

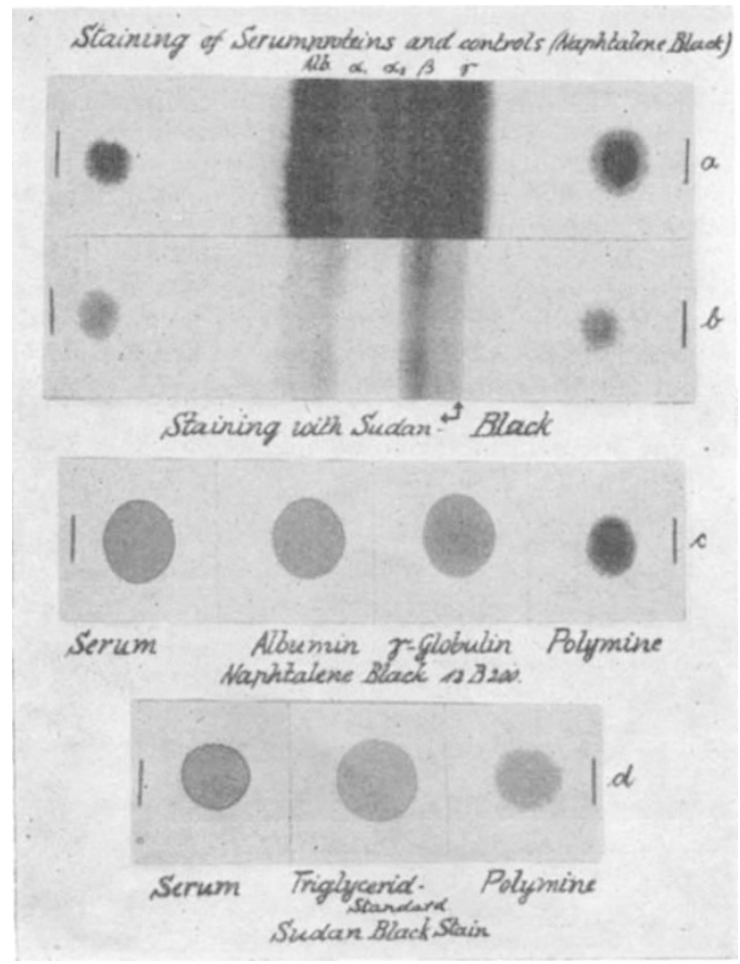

Fig. 1
Table 1

\begin{tabular}{|c|c|c|c|c|}
\hline & $\begin{array}{l}\text { Volume } \\
\text { (ml.) }\end{array}$ & $\underset{(\gamma)}{\text { Amount }}$ & $\begin{array}{l}\text { Plani- } \\
\text { meter } \\
\text { reading }\end{array}$ & $\begin{array}{c}\text { First } \\
\text { standard } \\
\text { deviation }\end{array}$ \\
\hline $\begin{array}{l}\text { Stained with naphthalene } \\
\text { black }\end{array}$ & & & & \\
\hline Serum, dil. $1: 40$ & 0.02 & 35 & 0.92 & $1 \cdot 8$ \\
\hline Albumin, human & 0.02 & .30 & 0.90 & $1 \cdot 7$ \\
\hline $\begin{array}{l}\gamma \text {-Globulin, human } \\
\text { 'Polymine' (0.05 per cent) }\end{array}$ & $\begin{array}{l}0.02 \\
0.02\end{array}$ & $\begin{array}{l}30 \\
10\end{array}$ & $\begin{array}{l}0.83 \\
1.00\end{array}$ & $\begin{array}{l}1 \cdot 6 \\
2 \cdot 0\end{array}$ \\
\hline Stained with sudan black & & & & \\
\hline Serum, dil. $1: 1$ & 0.02 & $\begin{array}{l}150 \\
\text { (lipids) }\end{array}$ & $1 \cdot 25$ & $1 \cdot 7$ \\
\hline $\begin{array}{l}\text { Triglyceride-standard } \\
\text { 'Polymine' ( } 0.05 \text { per cent) }\end{array}$ & $\begin{array}{l}0.02 \\
0.03\end{array}$ & $\begin{array}{l}80 \\
15\end{array}$ & $\begin{array}{l}1 \cdot 20 \\
1 \cdot 00\end{array}$ & $\begin{array}{l}1 \cdot 5 \\
2 \cdot 7\end{array}$ \\
\hline
\end{tabular}

proteins (Whatman paper No. $1, p \mathrm{H} 8 \cdot 6,10 \mathrm{~V} . / \mathrm{cm}$.) and a spot of $0.02 \mathrm{ml}$. 'Polymine' standard on each side. Strip $a$ has been stained with naphthalene black and strip $b$ with sudan black. It is well known that in pathological sera the uptake of dyes is variable; in such cases the 'Polymine' standard can serve as a reference because the solubility interrelationships between dye, solvent and polybase are constant.

On paper strip $c$ the staining of some proteins with naphthalene black is compared with the staining of the 'Polymine' standard on the right. Paper strip $d$, is stained with sudan black; in the middle section there is a drop of $0.02 \mathrm{ml}$. of triglyceride standard, containing $60 \gamma$ of triolein and $20 \gamma$ of tristearate, which we have used ${ }^{1}$ as reference for lipoprotein staining. The spot on the left of it is a drop of $0.02 \mathrm{ml}$. of normal serum diluted $1: 1$ with sodium chloride (physiol.). The dye uptake of such a drop gives a fair measure of the total lipids of the serum. Table 1 shows the mean results of twenty-five spots of each substance, as read in the electronic densitometer Model 525 of the Photovolt Corp.

The different diffusion (spread) of the spherical colloids (proteins) and the linear colloid ('Polymine') is noticeable.

Ch. Wunderly

Medical University Clinic, Zurich.

Nov. 28.

${ }^{1}$ Wunderly, Ch., and Wieme, R. J., Arch. Int. Physiol. Biochem., 63 318 (1955).

\section{A New Solvent for Quantitative Paper Chromatography of Sugars}

Many mobile phases are found in the paper chromatography of sugars; but the separation of sucrose, fructose and glucose is somewhat difficult, because their $R_{F}$ values are very near each other ${ }^{1}$. The separation is enough for identification purposes, but it is not good enough for elution or photometric readings, because the sugars are still partly mixed. The solvent suggested below divides the sugars quite well with the following $R_{F}$ values (at $20^{\circ} \mathrm{C}$.) : sucrose, 0.17 ; glucose, 0.26 ; mannose, 0.30 ; arabinose, 0.32 ; fructose, 0.32 ; xylose, 0.33 ; ribose, $0 \cdot 41$.

The solvent, which was studied for non-volatile organic acids ${ }^{2}$, is : normal propyl alcohol, 50 c.c .; benzyl alcohol, 72 c.c. ; water, 20 c.c. ; 85 per cent formic acid, 20 c.c. It must be freshly prepared. The photometric readings give with this solvent a graph of well-separated curves, so that errors due to the computation of common areas are eliminated. 